\title{
US imperial hegemony in the American Pacific
}

\author{
Oliver Turner
}

\section{Introduction}

The question of this volume, as important as it is, is not simply of what legacy Barack Obama leaves in the Indo-Pacific after eight years in office, or, indeed, of how Donald Trump has engaged with that legacy during his first two years in charge. It is of the historical legacies of American power in the twenty-first-century Indo-Pacific of which both Obama and Trump themselves are constituted, which frame and steer their ideas and actions, and which they challenge or reinforce. Individuals and their administrations matter, but so do underlying knowledges and truths about the world which endure, sometimes for centuries, to be inherited by new presidents and their advisors because they defy party politics and the whims and cycles of popular opinion. These are the legacies about which this chapter is concerned.

The argument is not that Obama, Trump or any other occupant of the White House is somehow irrelevant - that there exist timeless and all-powerful understandings about the United States and the Indo-Pacific which render any given president and their administration a helpless conduit of deterministic discourses or wisdoms. It is that in any discussion of presidential legacy, it is useful in the first instance to step back to assess the historical conditions which explain how they could come to be, and what the past tells us about their likely future direction.

This chapter begins by speaking to debates around whether US internationalism represents empire or hegemony, and their applicability to the United States' place in Asia and the Pacific. To make sense of that place and its varied manifestations across space and time, it is argued that the United States has consistently pursued a position of imperial hegemony throughout the Asia Pacific (rather than the wider Indo-Pacific, about which this volume in toto is concerned). The next section argues that, in this pursuit, the United States has sought to construct an American 
Pacific framed by the perceived civilisational values and physical authority of the American self. The formations of this American Pacific are traced from the earliest periods of US expansionism, showing how it has always been seen as an extension of US territory and identity. The chapter then turns to the 2009-17 presidency of Barack Obama and how his policies and worldviews were informed by centuries of historical logics about the United States and its role in the Asia Pacific. It also assesses what the first two years of the Donald Trump presidency reveal about the deep-rooted legacies of the American Pacific in the post-Obama era, not least with regard the re-imagining of the region into a larger "Indo-Pacific". The chapter concludes by arguing that key legacies of the American Pacific for twenty-firstcentury US administrations are of largely unquestioned truths about the United States as a local actor throughout a region imagined to extend from the Western United States to the furthest reaches of Asia, and that an ever-expanding reach of influence and authority has meant an ever-expanding responsibility to sustain and defend itself there.

\section{On American empire and hegemony}

Debates over whether the United States constitutes an empire are long-running and recently oxygenised by the aggressive unilateralism of the George W. Bush administration of 2001-09; Michael Mann criticised the post-9/11 American bid for Empire, ${ }^{1}$ while Bush-era imperialism also had its proponents. ${ }^{2}$ In 2000 Bush himself argued that 'America has never been an empire. In fact, we may be the only great power in history that had the chance, and refused. ${ }^{3}$ Jack Snyder agrees, arguing that the United States 'has no formal colonial empire and seeks none.. $\mathrm{On}$ the contrary, following its creation in 1776 the United States quickly acquired a colonial empire and never lost it. The United States, indeed, is perhaps the most efficient and "successful" colonial power in history; efficient in the speed and vigour by which it occupied and seized the central North American continent, and successful in how that occupation was legitimised in the name of civilisation, never to face retreat from the lands it claimed.

Beyond the settler colonialism of North America, it is claimed that any international US empire today is qualitatively different to those of the past. The United States, it is argued, has built an informal empire with institutional, rather than statecentric, formations. John Ikenberry argues that the American-led global system is organised by consent-based networks of rules, institutions and partnerships, with the term hegemony more appropriate than 'misleading' assertions of empire or imperialism. ${ }^{5}$ Andrew Hurrell concurs, but suggests that notions of an institutional American empire often neglect the centrality of force and coercion to US foreign policy, and its intrusions into others' domestic affairs. ${ }^{6}$ 
As suggested by Ikenberry who sees a deeply rooted 'neo-imperial logic' in US political culture, ${ }^{7}$ hegemony and empire are not mutually exclusive. Charles Maier, indeed, laments the polarising nature of the word empire and resists its application to the United States which, he says, 'reveals many, but not all ... of the traits that have distinguished empires' of the past. ${ }^{8}$ For Maier, empire is not only the accumulation of foreign lands, but the processes by which 'the social elements that rule in the dominant state ... create a network of allied elites in regions abroad who accept subordination ... in return for the security of their position in their own administrative unit (the "colony" or, in spatial terms, the "periphery").' Robert Young similarly sees imperialism as 'the exercise of power either through direct conquest or (latterly) through political and economic influence. Imperialism, in this view, is 'the deliberate product of a political machine that rules from the centre, and extends its control to the furthest reaches of the peripheries.' ${ }^{10}$

Following these debates, it is understood here that the historical and contemporary American presence throughout the Asia Pacific is not easily termed either empire or hegemony. Difficulties emerge primarily from radical variations in the spatio-temporal contours of that presence across the region; stark differences in the interactions with US power and influence experienced by China, the Philippines and Australia, to name just three - including at various points throughout their own histories - make single, uniform designations such as empire or hegemony analytically problematic. With its devastating defeat and occupation by the United States in 1945 and the subsequent rewriting of its constitution by American officials, for example, Japan has been more exposed to violently imperialistic dimensions of American military and political power than almost anywhere else. Yet Japan formally retained its sovereignty. With US support it also experienced rapid economic growth for much of the Cold War and entered a close security alliance with Washington in which it remains a willing participant today. Elsewhere, of course, US authority has been comparatively absent, more typically within continental than maritime Asia.

What more meaningfully binds the encounters of the multitudinous actors of Asia and the Pacific with the regional American presence is the United States' centuries-long project of what is termed here imperial hegemony. As will be shown, this project has always been designed to realise a hegemonic region-wide influence of American identity and its core values and practices. US imperial hegemony in the Asia Pacific has, particularly in the post-1945 era, utilised Ikenberry's consent and rules-based networks of institutions and partnerships. Yet the establishment and maintenance of those networks has always been enabled by the availability, and sometimes direct use of, superior material power. Arguments of informal US empire or hegemony can thus be overly myopic, with "willing" partners such as Japan and the Philippines the previously unwilling recipients of overt, imperialistic US political expansion and military power from at least the 
mid-to-late nineteenth century, as the long-term conditions for core American values were aggressively moulded.

To speak of US imperial hegemony, then, is to look to the institutionalised and even consensual formations of American power where they are found, while affording serious concern to their fundamental reliance upon varyingly intensive impositions of political and economic systems and administrative rule - and even physical conquest - alongside the critical role of the American military, in enabling the exertion of sometimes violent control from the centre to the peripheries. The aim is to make sense of the complex and uneven landscape of the American presence across Asia and the Pacific; the United States may not have achieved a ubiquitous dominance or hegemony of material and ideational power, but its efforts at imperial hegemony have, as explored below, been sustained and ubiquitous in scope. The argument, it should also be noted, is not that these efforts have been uniformly unwelcome and/or harmful. Like in Europe, post-war US involvement in Asia and the Pacific has, at least for some, constituted something akin to an 'empire by invitation." ${ }^{11}$

\section{The formations of an American Pacific}

The region we know today as the Asia Pacific is not a natural entity. Beliefs that an Asia Pacific exists, indeed, are traced only to the 1970s and an emphasis on increasing interconnections between North America and East Asia and ongoing regional US security concerns. ${ }^{12}$ As an imaginative geography, the Asia Pacific along with its constituent actors are socially and politically spatialised, or geographed. ${ }^{13}$ Their physical realities are made up of powerful ideas, so that regional US activities have always been at least partly determined by understandings about the American self and its Enlightenment-inspired, democratic-capitalist values.

In its pursuit of imperial hegemony throughout the Asia Pacific, the United States has sought to establish and maintain an American Pacific. This is a geography of the imagination as much as the physical Earth, where civilisational ideas and values perceived to represent the core of the American self - democracy, freedom and liberty, and its capitalist economic system ${ }^{14}$ - as well as material dominance, are seen to be required. As a space defined by the operations of US power and values, as we will see, the American Pacific has been conceived in Washington not just as a site of material competition, but more fundamentally an extension both of US territory and identity, to legitimise its defence against those who seek to threaten and/or rework it.

Early US presidents like Thomas Jefferson declared a need to avoid 'entangling alliances' abroad. ${ }^{15}$ John Quincy Adams argued that Washington should refrain from searching the world for 'monsters to destroy. ${ }^{16}$ Yet the nascent United States 
set out to discipline and civilise Native Americans of the then-foreign lands of North America. With "monsters" in its near-neighbourhood and "empty" spaces to occupy, the United States had no cause for risky internationalism overseas. Instead, it engaged in an internationalist project to seize the continent. The appellation Expansion Era - used to describe the United States' rapid territorial and economic growth during the nineteenth century - subtly glorifies intensive and violent colonialism.

Frederick Jackson Turner observed that territorial US expansion towards Asia was a 'logical outcome' of this westward march to the Pacific. ${ }^{17}$ What mattered was not just physical geography, but the mythical frontier which has always been an opportunity for the United States to inflate what Jefferson envisioned as an Empire for Liberty. With American self-identity forged not around an ethnic group or religion but powerful principles of freedom, liberty, modernity, and so on, the United States is 'peculiarly dependent upon representational practices for its being. ${ }^{18}$ As such, a frontier to be conquered has always been necessary to the United States, for without it the nation would stagnate and risk losing its purpose, or Manifest Destiny, of advancing the global good. ${ }^{19}$ 'American democracy', argued Turner, 'gained new strength each time it touched a new frontier. ${ }^{20}$ Ultimately, the American frontier has always been conceived as 'the outer edge of the wave - the meeting point between savagery and civilization.' ${ }^{21}$

The United States began laying the foundations of a hegemonic presence in Asia and the Pacific and expanding its frontiers there in parallel with its colonial North American empire, with the gains of each simultaneously fuelling and rationalising the other. In 1844 for example when the Union consisted of just twenty-six states, Americans took advantage of imperial China's weakness after its defeat in the first Opium War with the British. Washington drew up the ("unequal") Treaty of Wanghia, which a shell-shocked Beijing promptly signed. The treaty was designed to help the United States exploit opportunities through China's forced abandonment of practices Washington and others considered anachronistic and uncivilised, such as quotas on foreign trade and prohibitions on foreigners in most Chinese ports. But the treaty was about more than economic gain. With the intention to Westernise China, it granted the United States privileges in diplomacy and law and gave Americans the previously forbidden right to learn the Chinese language. It worked to turn China into an overseas site not just of American profit but of the American self. ${ }^{22}$

Via the gunboat diplomacy of Matthew Perry's Black Ships, Washington signed the Treaty of Kanagawa with Edo (Tokyo) in 1854 which similarly required Japan to open its ports to American trade and refuelling vessels, and accept a resident US consul. Japan became another site of American political, economic and military power as its Pacific frontier further expanded; like China, Japan was geographed as backward and uncivilised to be forcibly aligned with Western norms of diplomacy and commerce, becoming a strategic layover for an increasingly ambitious 
American navy. Claims were made to, among others, Baker Island, Howland Island and Jarvis Island, and after its purchase in 1867 Alaska was transformed from a disconnected, largely ungoverned, majority Native American region, to a district, then a territory, and finally a state in 1959. By then its white population was three times larger than its Native population, and a new constitution remodelled its political structures in line with the bicameral legislatures of US states, with the creation of a Senate and House of Representatives.

The year 1898 was a landmark in the formation of the American Pacific when the United States claimed possession of Hawaii, Guam, and the Philippines from Spain. As in Alaska, Hawaii's legal and political institutions were restructured to conform to those of the United States, eventually transitioning to statehood in 1959. Military bases including Pearl Harbor were established on what was seen as a strategically valuable settlement. 'We need Hawaii just as much and a good deal more than we did California', asserted William McKinley in 1898. 'It is Manifest Destiny. ${ }^{23}$ The acquisition of Guam and its people meant that the island became another de facto US colony, under the jurisdiction of the Department of Defense and headed by a succession of US Navy-appointed governors. These governors had near absolute authority, with supreme legislative, executive and judicial oversight. Guamanians had no say in the choice of their governor or head of state, and with the island principally for use by the American armed forces, it was in effect an American-administered military dictatorship.

During the Pacific war with Japan in the 1940s, the island societies of Hawaii ${ }^{24}$ and Guam ${ }^{25}$ were stripped to their essential elements in the US imagination, with President Franklin Roosevelt grouping them with the uninhabited islands of Wake and Midway as strategic 'outposts' of military-security concern. The 1950 Guam Organic Act passed jurisdiction of the island and its people to the Department of the Interior. Guam's reclassification as an unincorporated organised territory enabled partial self-governance and democracy for Guamanians, but restricted their representation in American politics and codified their location at the political and societal periphery. Washington exerted colonial authority over the Philippines until 1946. From the beginning, the aim of the United States (in the words of former US Secretary of the Philippine Commission) was to transplant 'the ideas and improvements of one civilization upon another. ${ }^{26}$ Even after granting the Philippines independence, the United States continued to intervene in its affairs and the Military Bases Agreement of 1947, which gifted Washington rent-free control of Clark airbase and Subic Bay naval base, was signed by a Filipino elite with personal motivations. ${ }^{27}$ Both served as key Cold War US military hubs.

The Cold War saw the foundations of the American Pacific considerably widened and reinforced, with permanent military presences established in Japan following the close of the Second World War, and on the Korean Peninsula from the outbreak of the Korean War. More than 550,000 US troops were stationed in East Asia in 1953, with numbers peaking in the late 1960s at nearly $800,000 .^{28}$ 
President Dwight D. Eisenhower invoked the myth of the American frontier when he argued that the Korean War was being fought on the 'frontier of freedom, ${ }^{29}$ and that South Vietnam, South Korea and Taiwan were 'frontier nations' in the struggle against communism. ${ }^{30}$ President John F. Kennedy later spoke of reinforcing the 'frontiers of freedom' in Vietnam, to counter the non-democratic north. ${ }^{31}$ East and Southeast Asia were spatialised in a way that brought faraway conflicts closer to home, to within the boundaries of an American Pacific whose "domestic" political cultures, economic and trade norms, military-security outposts, and even white populations had to be defended. Distant South Vietnam, South Korea and others were seen as vulnerable extensions of US territory and identity, at the outer edge of the wave between the civilised and non-civilised.

From the 1970s, US troop numbers in Asia decreased through to the end of the Cold War in $1989 .{ }^{32}$ Yet to a significant extent the Cold War in East Asia, not least for Washington's security establishment, endured in a zombie-like form. The war on the Korean Peninsula went unresolved, while communism (or more accurately, authoritarianism), unlike in Europe, survived in Laos, North Korea, Vietnam and elsewhere. A rising China filled the communist threat void left in American imaginations by the collapsed Soviet Union, and the United States retained heavy military presences in Japan, South Korea and Guam, as well as its extensive hub and spokes system of regional security alliances and treaties.

\section{Twenty-first-century legacies of the American Pacific}

\section{The Obama presidency, 2009-17}

As an imaginative geography, the material realities of the Asia Pacific and its actors remain constitutive of particular ideas which give them meaning, and it is here that we find powerful legacies of the American Pacific throughout Obama's two-term approach to the region. In particular, the so-called Pivot or Rebalance to Asia formally announced in late 2011, was the flagship international policy of the Obama presidency. The Pivot was envisioned as a grand strategic shift of US attention and resources from the post-9/11 theatres of Iraq and Afghanistan to a region deemed of foremost long-term significance. Most typically, it has been interpreted by observers as a response to the physical "rise" of China. ${ }^{33}$ However, the decision to Pivot to Asia was grounded not simply on understandings of a new material competitor and its physical impacts on regional dynamics.

During the Obama era (as before and since) large, rapidly rising India failed to generate significant security concerns in Washington. The Obama administration repeatedly emphasised India's democratic credentials and shared values, seeking closer and more cooperative ties. India was a rising power, but importantly too a 
particular rising identity which reaffirmed the liberal-democratic identity of the United States. Non-democratic rising China, meanwhile, was seen to contradict the American self. It was routinely described as fundamentally different, requiring guidance and discipline and presenting a challenge to regional order. While China's physical capabilities expanded more rapidly than India’s, this alone fails to explain Obama-era contrasts in US policy and perception. ${ }^{34}$

As we have seen, China, alongside regional others, has throughout history been understood to lack such essential standards of civilisation as Western-style democracy, liberty and capitalism. The 1844 Treaty of Wanghia was designed to export these values to China and advance the frontiers of the American Pacific. In a 2015 statement on the main economic pillar of the Pivot, the Trans-Pacific Partnership (TPP), Obama argued that 'we can't let countries like China write the rules of the global economy. We should write those rules. ${ }^{35}$ Whatever the normative arguments around the merits or dangers of a Chinese-led global economy, 'countries like China' was code for those who still lack a full display of civilised values. The planned inclusion in the TPP of non-democratic Vietnam and Brunei demonstrates that China's physical contours were not irrelevant. However, the Pivot was no mere realpolitik response to the challenges and/or threats posed by the capabilities of a material competitor. Obama's Secretary of State John Kerry remarked that 'The United States and China ... have different political systems, different histories, different cultures, and ... different views on certain significant issues. ${ }^{36}$ By most measures this applies equally to the United States and India. Yet there the focus was on naturally closer ties, 'rooted in common values and interests. ${ }^{37}$ In sum, 'India's rise is not simply less dramatic and quantitatively different to China's; in American imaginations it is qualitatively so. ${ }^{38}$

Modern political leaders, rarely, if ever, speak of Empires for Liberty or the savagery or barbarism of others. In 2014, however, Obama explicitly echoed Eisenhower, Kennedy and others when he identified the boundary between South and North Korea as 'freedom's frontier'. South Korea is 'a country like ours', he asserted, and ' $[\mathrm{t}$ ] he 38th Parallel now exists as much as a contrast between worlds as it does a border between nations. ${ }^{39}$ Countries 'like ours' were (and remain) embodied by the American Pacific, where a traditional US hegemony of ideas and the authority to enforce them had to endure. As Secretary of State Hillary Clinton explained, the Pivot was formulated to 'sustain our leadership, secure our interests, and advance our values. ${ }^{40}$ Guam could also be seamlessly reduced to Roosevelt's strategic 'outpost'; for Obama the island was a 'strategic hub', to which he decided he could transfer thousands of US troops from Japan without significant controversy. ${ }^{41} \mathrm{As}$ it has since the late nineteenth century, the US military remained in effective control of Guam, occupying almost 30 per cent of the island and keeping the society and its people reliant upon its economic presence.

As will be shown throughout the remainder of this volume, Obama distinguished himself in important ways from presidential predecessors in 
Asia, leaving legacies of his own making. Equally, however, Obama came late to ingrained understandings of the region and the United States' place within it. His policies and worldviews were to some extent themselves the legacies of centuries of US imperial hegemony in a fantasised American Pacific he inherited and subscribed to. The Obama administration mantra, for instance, was of the United States as a Pacific power or nation. It was a term historically driven to situate the United States as an organic resident of the Pacific in toto, perpetuating the essentially unquestioned necessity of a Pacific-wide reach of US activity and influence. The term "Pacific power/nation" was 'an inherently performative call to action, turning foreign problems into domestic problems by helping to ensure that the United States acts in distant Asia as naturally as Vietnam, the Philippines, and, most importantly, China. ${ }^{42}$

For the Obama administration, then, China was not rising in a distant Asia Pacific, but into a geographed American Pacific defined by American values, where long-standing US imperial hegemony was now increasingly questioned. It remained an extension of US territory and of the American self, justifying, as Obama explained, 'a larger and long-term role in shaping this region and its future. ${ }^{43}$ To this end, Obama pledged to increase the proportion of the US naval fleet in the Pacific to 60 per cent by 2020, and from 2012 a new contingent of US marines was stationed in Australia. Washington strengthened security ties with the Philippines, Singapore, Vietnam and others, and regional US arms sales increased. As an imaginative geography it could also still be reconstructed at will; Clinton argued that it stretched 'from the Indian subcontinent to the western shores of the Americas, ${ }^{44}$ inflating its traditionally accepted boundaries.

When Obama came to office in early 2009 the United States had approximately 79,000 military personnel stationed throughout the Asia Pacific. By the end of his second term in 2016 there remained approximately $68,000,{ }^{45}$ a decline of around 15 per cent, but in line with post-Cold War trends. A fuller retreat from the imaginary frontier (the existence of which, as we have seen, Obama explicitly acknowledged), still conveniently reified in such places as the Korean border and US military bases in Japan and Guam, could conceivably have been achieved; at the time of Obama's election victory in 2008, nearly half of Americans believed the United States spent too much on its military, the highest proportion since the early 1990s. ${ }^{46}$ Significant proportions of Americans (just as now) also believed that the United States should abandon its military bases in Japan. ${ }^{47}$

To withdraw, however, would have been to implicitly validate the other, less civilised world of which Obama spoke at a time when his administration was actively promoting a regional Pivot designed, at least in part, to contain its influence in the form of a rising anti-democratic China and ongoing threats from a nuclear-arming North Korea. Fundamentally, it would have challenged ingrained and traditionally unquestioned truths of the United States as a resident actor, even in the furthest reaches of the region. In Hawaii and Guam the United States 
boasted territorial sovereignty and in Japan, South Korea and elsewhere its political and economic systems had been exported, remaining vulnerable to threatening influences from the peripheries. Centuries of US political discourse to this effect had been deployed to legitimise wide-ranging internationalist projects in the Asia Pacific, often at great cost, and they could not be overturned by one administration, even had the will existed.

\section{The early Trump presidency, 2017-19}

Donald Trump is an aberration within the roll call of American presidents. He is the least formally qualified, having never previously occupied political office, and the only one to have seriously questioned Washington's post-war commitments to the so-called US-dominated world order. In the Asia Pacific, President-elect Trump's conversation in late 2016 with Taiwanese leader Tsai Ing-wen broke decades of carefully maintained protocol with China; his praise for controversial Philippine President Rodrigo Duterte was a characteristically Trumpian departure from diplomatic norms; and his rhetoric towards North Korea and willingness to engage directly with Kim Jong-un has been a radical shift from the strategic patience of his predecessors. While the means by which the Trump administration seeks to advance American interests might diverge significantly from those of Obama and his predecessors, however, we find in its regional strategies longspoken truths and historical legacies of US imperial hegemony, and powerful underlying continuities of policy and worldview.

Trump's first US National Security Strategy (NSS), for example, pledged to 'rebuild our military, defend our borders, protect our sovereignty, and advance our values. ${ }^{48}$ It argues not simply that China (alongside Russia) is a material competitor, but a 'revisionist' nation looking 'to shape a world antithetical to US values and interests. With China promoting authoritarianism and expanding its statecentric economic model, it explains, 'a geopolitical competition between free and repressive visions of world order is taking place in the Indo-Pacific region'. Just like the Asia Pacific during the Obama era, the Indo-Pacific - a term increasingly normalised under Trump, for example with the US Navy's Pacific Command renamed the US Indo-Pacific Command - is imagined to stretch 'from the west coast of India to the western shores of the United States. ${ }^{49}$

Regular references not simply to an Indo-Pacific, but to a 'free and open Indo-Pacific', confirm its endurance as a fantasised extension of American territory and identity. A Trilateral Dialogue with India and Japan established in 2011 (alongside a Trilateral Strategic Dialogue with Japan and Australia) continued under Trump, intensifying in mid-2018 with a collaborative infrastructure plan..$^{50}$ Democratic India, whose economy is projected to overtake that of the United States before 2050, remains conceived as a strategic partner central to 'a rules-based order. ${ }^{51}$ The option of withdrawing from the frontier 
in Asia stays beyond mainstream debate, even for this most unorthodox of administrations, with Secretary of State Mike Pompeo explaining that the United States is committed to growing our presence in the region. ${ }^{52}$ The 2017 NSS echoes Eisenhower, Kennedy and Obama by pointing to the importance of America's frontier nations of Japan, South Korea and Taiwan in regard to North Korean aggression and in defence of the One China policy. The Trump administration, indeed, is firmly committed to the United States' 'forward military presence' in the Asia Pacific ${ }^{53}$ and, to a significant extent, like those of Obama, Bush and Clinton before it, continues to act out the Cold War in the region. The long-term decline in the regional US troop presence will likely persist at least in the short term, but essential Cold War structures remain intact, most notably in its regional military bases and hub and spokes network of alliances which, with exceptions such as Vietnam, prioritises non-authoritarian allies.

The Asia Pacific and, increasingly, the Indo-Pacific, under Trump, then, has remained an American Pacific, as an imaginative geography of the American self defined by the twin requirement for its core values of Western-style democracy/freedom and capitalism, and its physical authority, to endure. Under Trump, the United States continues to pursue imperial hegemony in the region through institutionalised and consensual, or Ikenberry's 'informal', networks of power; Secretaries of State Rex Tillerson and Mike Pompeo attended the ASEAN Regional Forums of 2017 and 2018 respectively and the United States seems willing to remain an active participant of the multilateral landscape. The maintenance of those networks, however, continues to be enabled by the explicit availability and impositions of political/economic and military power, with some more exposed than others.

The Trump White House, for example, has so far avoided such staples of postwar US foreign policy discourse as democracy promotion and the protection of human rights, while continually restating its seemingly hard power foreign policy doctrine of "America First", including in Asia, with its focus on revising trade and other economic agreements in favour of US interests and strengthening the American military. Yet as we have seen, the basis for American engagement adheres to historically familiar, value-driven logics of the American self. Washington still assesses regional partnerships, not least its "great power relations" with India and China, on the presence or absence of shared political values. ${ }^{54}$ In early 2018 the Trump administration withdrew financial assistance to Cambodia over 'setbacks to democracy' there. ${ }^{55}$ Typically now in the absence of physical conquest, the United States still manipulates the long-term conditions for American values to exert control from the centre to the peripheries; '[T]he US Government doesn't tell American companies what to do, explained Secretary of State Pompeo at the Indo-Pacific Business Forum. 'But we help build environments that foster good, productive capitalism. We help American firms succeed so that local communities can flourish, and bilateral partnerships can grow. ${ }^{56}$ 
In the military-security realm, the Trump administration actioned the Enhanced Defense Cooperation Agreement (EDCA) with the Philippines, formulated under Obama, to help reassert regional US authority from one of its traditional military hubs. Like the Military Bases Agreement of 1947, controversy followed the EDCA after being approved only by the Philippine Executive, bypassing scrutiny from the Senate. ${ }^{57}$ Obama-era plans to relocate troops from Okinawa to Guam also remain in place, so that the island under Trump, still denied full democratic representation, stays conceived first and foremost as a strategically valuable outpost for use by, and deployment of, the US military. As noted by Secretary of Defense James Mattis: ' $[\mathrm{H}]$ aving these forces on US territory, whether it be Guam or Hawaii ... allows us certain freedoms of actions and sustainment out there. ${ }^{58}$

\section{Conclusion}

Washington's policy makers ascribe to long ingrained truths of the United States as a local Pacific Power, in an American Pacific imagined to extend from the Western United States into the furthest reaches of Asia. Like Obama, the Trump administration uses history to sustain the normality of an American presence many thousands of kilometres from the US mainland: ' $t$ the US interest in a free and open Indo-Pacific extends back to the earliest days of our republic, ${ }^{59}$ notes the 2017 NSS, reasserting Washington's timeless project to secure its Enlightenmentinspired, democratic-capitalist values. As ever, this project primes Washington to see threats in those whose values contradict the American self. With the reach of American power and identity throughout the Asia, and now Indo-, Pacific expanding over time in the forms of domestic political cultures, economic and trade norms, military bases and outposts, and, in places, its dominant linguistic and racial foundations, perceived responsibility over their maintenance and defence has expanded with them. These are key legacies of the American Pacific for twenty-first-century American presidents.

These physical and ideational legacies have been centuries in the making and play a key role in the contemporary operations of US foreign policy. Having steadily, if unevenly, transformed the landscape of the region from at least the middle of the nineteenth century, from Alaska to Guam to the Philippines to Japan and beyond, the United States maintains its pursuit of regional imperial hegemony today. It does so through institutionalised and consensual networks of partners and allies, enabled by the availability and application of political/economic and military power to extend control from the centre out to vulnerable frontiers. Washington's Cold War security frameworks, in Japan and Korea and in its hub and spokes network of bilateral alliances, are maintained in a region seen as one of rising challenges as much as economic development. But the United States keeps a Cold War on life support which, for most, ended thirty years ago. 
Authoritarian China is now the largest trade partner and among the largest investment partners of almost every Asian economy. Most regional governments also strongly favour a plurality of regional power where no single actor dominates; a rising China generates uncertainties and tensions, but from a position of preponderance the United States has a long history of forceful and destructive impositions. In historically familiar ("civilised vs. uncivilised") terms, the Obama and Trump administrations have identified the existence of two distinct worlds: one defined by the operations of American values and the other by their problematic absence. Yet even where democracy and capitalism thrive in Asia, the region has commonly conformed to Western models only in Western imaginations. ${ }^{60}$ In today's less polarised post-Cold War world, moreover, regimes which have long resisted US democratisation efforts now feel emboldened and tacitly supported by China's state-centric rise.

Diplomatic and security allegiances in the Indo-Pacific, then, are evolving and its geopolitical contours are increasingly fluid. The United States must also adapt, but questions remain over the extent to which it is willing to do so and how it will make sense of the first long-term diminishments in its regional grip on ideas and physical power in at least 150 years. Historical legacies of the American Pacific haunt twentyfirst-century Washington administrations, handing down the responsibility to sustain US authority throughout an ever-inflating imaginative geography now reconstructed from an "Asia" to an "Indo" Pacific. Yet established truths can be challenged and cycles of policy can be broken. Today more than ever, radical thinking towards Asia and the Pacific in Washington's foreign policy circles is required.

\section{Notes}

1 M. Mann, Incoherent Empire (London: Verso, 2003), p. 16.

2 For example, S. Mallaby, 'The reluctant imperialist: Terrorism, failed states, and the case for American empire', Foreign Affairs, 81:2 (2002), pp. 2-7.

3 G. H. W. Bush quoted in K. Raustiala, 'America Abroad: US May Not Be Imperial, But It Does Have an Empire', New York Times (2 July 2003), www.nytimes.com/ 2003/07/02/opinion/IHT-america-abroad-us-may-not-be-imperial-but-it-doeshave-an-empire.html, accessed 5 March 2019.

4 J. Snyder, 'Imperial temptations', The National Interest, 71 (2003), p. 29.

5 J. Ikenberry, 'Power and liberal order: America's postwar world order in transition', International Relations of the Asia Pacific, 5:2 (2005), p. 149.

6 A. Hurrell, 'Pax Americana or the empire of insecurity?', International Relations of the Asia Pacific, 5:2 (2005), pp. 153-76. The US-led liberal international order is argued elsewhere to be a class-based hegemony underpinned by colonial/imperial (as well as racial) thinking. See I. Parmar, 'The US-led liberal order: Imperialism by another name?', International Affairs, 94:1 (2018), pp. 151-72. 
7 Ikenberry, 'Power and liberal order', p. 136.

8 C. Maier, Among Empires: American Ascendancy and its Predecessors (Cambridge, MA: Harvard University Press, 2006), p. 7.

9 Ibid., p. 3.

10 R. Young, Postcolonialism: An Historical Introduction (Oxford: Oxford University Press, 2016), p. 27.

11 G. Lundestad, 'Empire by invitation? The United States and Western Europe, 19451952', Journal of Peace Research, 23:3 (1986), pp. 263-77.

12 N. Bisley and A. Phillips, 'A rebalance to where? US strategic geography in Asia', Survival: Global Politics and Strategy, 55:5 (2013), p. 98.

13 E. Said, Orientalism (New York: Pantheon Books, 1978); G. Ó Tuathail, Critical Geopolitics (Minneapolis: University of Minnesota Press, 1996), p. 2.

14 F. Cameron, US Foreign Policy after the Cold War: Global Hegemon or Reluctant Sheriff?, 2nd edition (London: Routledge, 2002), p. 2.

15 T. Jefferson, 'First inaugural address', in B. Oberg (ed.), The Papers of Thomas Jefferson, Vol. 33 (Princeton, NJ: Princeton University Press, 2006), pp. 134-52.

16 Quoted in W. H. Seward, Life and Public Services of John Quincy Adams (New York: Miller, Orton and Mulligan, 1856), p. 132.

17 F. J. Turner, The Significance of the Frontier in American History (New York: Henry Holt and Company, 1921), p. 315.

18 D. Campbell, Writing Security: United States Foreign Policy and the Politics of Identity (Minneapolis: University of Minnesota Press, 1992), p. 105.

19 D. Madsen, American Exceptionalism (Edinburgh: Edinburgh University Press, 1998), pp. 1-2.

20 Turner, The Significance of the Frontier, p. 293.

21 Ibid., p. 3.

22 O. Turner, American Images of China: Identity, Power, Policy (London: Routledge, 2014), pp. 48-9.

23 Quoted in H. W. Morgan, William McKinley and His America, revised edition (London: The Kent State University Press, 2003), p. 225.

24 F. D. Roosevelt, 'Address to the Congress on the State of the Union. January 6, 1942', in Public Papers of the Presidents of the United States: Franklin D. Roosevelt, 1942, Vol. 11 (New York: Macmillan, 1942), p. 32.

25 F. D. Roosevelt, ' 127 . "We are going to win the war and we are going to win the peace that follows" - Fireside chat to the nation following the declaration of war with Japan. December 9, 1941', in Public Papers of the Presidents of the United States: Franklin D. Roosevelt, 1941, Vol. 10 (New York: Macmillan, 1941), p. 525.

26 Quoted in J. Go, 'Introduction', in J. Go and A. Foster (eds.), The American Colonial State in the Philippines: Global Perspectives (London: Duke University Press, 2003), p. 1.

27 See A. Yeo, Activists, Alliances, and Anti-US Base Protests (Cambridge: Cambridge University Press, 2011), pp. 37-43. 
28 T. Kane, 'Global US Troop Deployment, 1950-2005', The Heritage Foundation (24 May 2006), www.heritage.org/defense/report/global-us-troop-deployment1950-2005, accessed 6 March 2019, p. 7.

29 D. D. Eisenhower, 'Remarks at the headquarters of the Korean Army's Sixth Corps. June 20, 1960', in Public Papers of the Presidents of the United States: Dwight D. Eisenhower, January 1, 1960 to January 20, 1961 (Washington, DC: Government Printing Office, 1961), p. 520.

30 D. D. Eisenhower, 'Special message to the Congress on the Mutual Security Program. February 16, 1960', in ibid., p. 183.

31 J. F. Kennedy, 'Special Message by the President on Urgent National Needs' (25 May 1961), www.jfklibrary.org/Asset-Viewer/Archives/JFKPOF-034-030.aspx, accessed 6 March 2019.

32 Kane, 'Global US Troop Deployment'.

33 For example, E. Ratner, 'Rebalancing to Asia with an insecure China', The Washington Quarterly, 36:2 (2013), pp. 21-38; C. Le Mière, 'Rebalancing the burden in East Asia', Survival: Global Politics and Strategy, 55:2 (2013), pp. 31-41. On the connotations of the term 'rising' see Turner, American Images of China, pp. 152-3.

34 See O. Turner, 'China, India and the US rebalance to the Asia Pacific: The geopolitics of rising identities', Geopolitics, 21:4 (2016), pp. 922-44.

35 White House, 'Statement by the President on the Trans-Pacific Partnership' (5 October 2015), https://obamawhitehouse.archives.gov/the-press-office/2015/10/ 05/statement-president-trans-pacific-partnership, accessed 6 March 2019.

36 US Department of State, 'Remarks on US-China Relations' (4 November 2014), https://2009-2017.state.gov/secretary/remarks/2014/11/233705.htm, accessed 6 March 2019.

37 H. Clinton, 'America's Pacific Century', Foreign Policy (11 October 2011), http:// foreignpolicy.com/2011/10/11/americas-pacific-century/, accessed 6 March 2019.

38 Turner, 'China, India and the US rebalance', p. 934.

39 White House, 'Remarks by President Obama to US Troops and Personnel at US Army Garrison Yongsan' (26 April 2014), https://obamawhitehouse.archives.gov/ the-press-office/2014/04/26/remarks-president-obama-us-troops-and-personnelus-army-garrison-yongsan, accessed 6 March 2019.

40 Clinton, 'America's Pacific Century'.

41 Ministry of Foreign Affairs of Japan, 'US-Japan Joint Statement: The United States and Japan: Shaping the Future of the Asia Pacific and Beyond' (25 April 2014), www.mofa.go.jp/na/na1/us/page24e_000045.html, accessed 6 March 2019; B. Kovach and C. Carter, 'US-Japan Deal Withdraws 9,000 Marines from Okinawa' (27 April 2012), https://edition.cnn.com/2012/04/27/world/asia/japanus-okinawa/index.html, accessed 6 March 2019.

42 Turner, 'China, India and the US rebalance', p. 933.

43 White House, 'Remarks by President Obama to the Australian Parliament' (17 November 2011), https://obamawhitehouse.archives.gov/the-press-office/2011/11/ 17/remarks-president-obama-australian-parliament, accessed 6 March 2019. 
44 Clinton, 'America’s Pacific Century'.

45 Defense Manpower Data Center, 'DoD Personnel, Workforce Reports, \& Publications' (2018), www.dmdc.osd.mil/appj/dwp/dwp_reports.jsp, accessed 6 March 2019.

46 Gallup, 'Americans Not Convinced US Needs to Spend More on Defense' (21 February 2018), https://news.gallup.com/poll/228137/americans-not-convincedneeds-spend-defense.aspx, accessed 6 March 2019.

47 The Chicago Council on Global Affairs, 'Public Opinion and the US-Japan Alliance at the Outset of the Trump Administration' (17 February 2017), www. thechicagocouncil.org/publication/public-opinion-and-us-japan-alliance-outsettrump-administration, accessed 7 March 2019.

48 White House, 'National Security Strategy of the United States of America' (December 2017), p. I.

49 Ibid., pp. 45-6.

50 US Department of State, 'Remarks on "America's Indo-Pacific Economic Vision" ' (30 July 2018), www.state.gov/secretary/remarks/2018/07/284722.htm, accessed 7 March 2019.

51 US Department of Defense, 'Mattis: Meeting With Indian Defense Minister Comes at Time of Strategic Convergence' (26 September 2017), www.defense.gov/News/ Article/Article/1325107/mattis-meeting-with-indian-defense-minister-comes-attime-of-strategic-converge/, accessed 7 March 2019.

52 US Department of State, 'Remarks on "America's Indo-Pacific Economic Vision"'.

53 White House, 'National Security Strategy', p. 47.

54 US Department of State, 'Remarks on "America's Indo-Pacific Economic Vision".

55 White House, 'Statement from the Press Secretary on Reduction in Assistance to the Government of Cambodia' (27 February 2018), www.whitehouse.gov/ briefings-statements/statement-press-secretary-reduction-assistance-governmentcambodia/, accessed 7 March 2019.

56 US Department of State, 'Remarks on "America's Indo-Pacific Economic Vision".

57 P. Parameswaran, 'Philippine Court Upholds New US Defense Pact', The Diplomat (12 January 2018), https://thediplomat.com/2016/01/philippine-court-upholdsnew-us-defense-pact/, accessed 7 March 2019.

58 S. Limtiaco, 'Defense Secretary Weighs in on Guam Role in Region', Pacific Daily News (21 June 2018), https://eu.guampdn.com/story/news/2017/06/21/defensesecretary-weighs-guam-role-region/414576001/, accessed 8 March 2019.

59 White House, 'National Security Strategy', p. 46.

60 See Turner, American Images of China. 